\title{
Camps of Containment: A Genealogy of the Refugee Camp
}

\section{Introduction}

As forced migration becomes an increasingly prominent global challenge, political responses to it demand closer scrutiny. This essay considers one of the most widely used responses to refugee flows, the refugee camp. For the past seventy years camps have been a primary response to forced migration. In 20I6, several hundred camps and settlements existed worldwide, housing more than twelve million refugees and internally displaced. ${ }^{1}$ From the Algerian desert to the Thai forest, these camps vary in almost every dimension. Some are the size of cities, while others are more like towns. Some are fenced and guarded, while others allow free movement. Some have existed for generations, while others are newly created. Amid such diversity, what do these spaces have in common? What is a refugee camp? This is a deceptively simple question, and one that has never been satisfactorily answered. Some authors have divided the universe of camps into categories, distinguishing (for example) selfsettlements, assisted self-settlements, and organized settlements. ${ }^{2}$ Others have focused on camps' institutional governance, and particularly on the role of international agencies in providing assistance as a (non-transparent, largely unaccountable) "surrogate state." ${ }^{3}$ Many more have sidestepped the problem entirely, recognizing refugee camps as spaces of contradiction—of "care and control," "compassion and repression" - that defy more specific definition. ${ }^{4}$

This failure to define the refugee camp has had consequences, not least of which has been to obscure the fact that such spaces are a distinct policy choice. Refugee camps are not an inevitable response to forced migration-in fact, their use is surprisingly recent, dating largely from post-I945. Yet there has been a marked lack of curiosity about the circumstances underlying camps' adoption and use. This essay seeks to address that oversight, arguing that to understand the refugee camp we must understand, or at least acknowledge, its antecedents. Undertaking such a historical analysis is again complicated by the lack of conceptual clarity of "the camp." Is a refugee camp sui generis or part of a wider complex of encampment? If the latter, what are its parameters? A basic definition of camps might include all sites that are spatially bounded and have a temporary existence: an immense variety of spaces, from Scout camps to protest camps. An alternative understanding is offered from political theorists who define "the camp" not as a primarily spatial entity but as a logic of power. Many scholars have applied Agamben's analysis of the concentration camp as "nomos of the modern" to the context of refugee camps, viewing the two sites as existing in parallel relationships of state violence and exception. ${ }^{5}$ Others have used a Foucauldian lens, examining the biopolitical nature of refugee camp administration 
and considering the camp as one component of a wide-ranging disciplinary technology of modern governance. ${ }^{6}$ These approaches capture important dimensions of camp governance, including an abrogation of sovereign functions by the hosting state and the administration of camps for a category of population. However, as an explanatory framework they are simultaneously too broad and too narrow: too broad, because biopolitical modes of governance and a relationship of exception are not specific to the camp but may exist in a multitude of sites and spaces; too narrow, because in focusing on power imposed from above they neglect the many ways in which camp residents negotiate, evade, and resist it.

Ultimately, analyses of the camp as biopolitical or a state of exception pay insufficient attention to the core function of a refugee camp, and the characteristic that makes this space fundamentally unlike other spaces of marginalization and exception: containment. Refugee camps exist to contain forced migrants until such time as they can return home or an alternative durable solution is possible. Certainly, the extent of containment varies. At one end of the spectrum lie refugee camps in Thailand or Kenya where residents are forbidden from leaving the camp boundaries. At the other extreme are camps where residents are free to work and travel, as in Uganda. Nevertheless, with varying degrees of institutional and legal formality, camps segregate their residents from a surrounding area. Even where freedom of movement exists, inherent in the concept of a camp is the imposition of a boundary between the camp space and the world beyond and thus the containment of residents within those bounds. ${ }^{7}$

This purpose of containment is fundamental to my argument. It is not a unique insight; other authors have also described segregation and "quarantine" as a defining function of the refugee camp. ${ }^{8}$ However, in this essay, I wish to go beyond simple recognition to explore its implications and consequences. This requires not merely acknowledging containment as the defining function of a refugee camp but recognizing containment as a particular type of encampment.

There are some caveats. First, not all containment occurs in camps. In refugee policy, the term "containment" has been used to describe a shift from asylum predicated on protecting mobility to asylum predicated on managing mobility, with the latter goal primarily achieved by containment in migrants' region or even country of origin. ${ }^{9}$ Physical confinement in camps is one mechanism for this, but containment may also be a consequence of other restrictions on refugees' freedom of movement (including, but by no means limited to, border security, visa controls, and immigration detention), or of a failure to facilitate lasting durable solutions that enable refugees and IDPs to escape their conditions.

Beyond the context of refugee situations, containment occurs in spaces of incarceration. Refugee camps are often compared to prisons, in an analogy of "total institutions." 10 There are certainly parallels between the two, but there are also important differences. Refugee camps are created and managed for categories of population; they are biopolitical. In contrast, prisons exemplify disciplinary power; they detain individuals on the basis of their individual actions. Furthermore, refugee camps have a temporary, politically conditional existence. If political circumstances change or an alternative durable solution is found, the camp no longer has a reason to exist. It must be stressed that "temporary" does not mean short-lived: experience has shown 
that once refugee camps are created they tend to stay in existence for many years, even decades. Nevertheless, even in the most long-standing encampment situations, such as for Palestinian refugees, camps were not desired or designed as permanent homes but were built as a temporary refuge until political circumstances changed. Prisons, in contrast, have a continuing existence, independent of the circumstances of one set of inmates.

Recognizing these features of a refugee camp makes the link with incarceration less compelling and the link with segregation more central. However, just as not all containment occurs in camps, not all camps are spaces of containment. Feigenbaum, Frenzel, and McCurdy note that the term "camp" derives from the Latin campus and since Roman times has had both leisure and military connotations. ${ }^{11}$ Leisure and military camps operate fundamentally to facilitate mobility. Camps created to constrain mobility are a more recent invention. A definition of the refugee camp must capture this dimension of containment, in addition to aspects of spatiality, political contingence, and biopolitical governance. As a definition of "camps of containment," then, I propose the following:

A site that is spatially bounded (i.e., it is an identifiable site); temporally limited (i.e., it exists pending an end to conflict or an alternative durable solution); is biopolitical (i.e., is designed and administered for a category of population rather than for individuals); and segregates residents from a surrounding population by formal or informal restrictions.

Each of these criteria is equally important. The spatial criterion distinguishes a camp of containment from more diffuse patterns of segregation (perhaps as in an urban "ghetto"). The temporal requirement distinguishes a camp of containment from a lasting political project to manage minority populations (a category that might include Indian reservations in the United States). The biopolitical dimension distinguishes camps containing a category of population from sites of detention based on individual sentencing. Finally, the dimension of segregation establishes the relationship of otherness and othering that is intrinsic to a camp of containment, Cumulatively, these criteria define a form of political governance that is surprisingly rare. Indeed, I have identified only three core categories of "camps of containment": prisoner-of-war camps, internment camps, and camps for forced migrants. A simple comparison of these categories would be misguided. Collectively, they represent thousands of camps created over more than two hundred years, affecting millions of lives. Furthermore, as I have argued elsewhere, every camp is a complex governance environment in its own right, the product of pluralistic legal and political interactions and of extensive historical and cultural influences. ${ }^{12}$

A broad historical comparison cannot hope to capture the complexity of each individual camp - but it has a different analytical value, potentially highlighting resonances between camps across the centuries and thus affording new insight into camps as a unique disciplining mechanism. In particular, a long-term perspective on the history of the camp highlights continuities in the model, showing "camps of containment" to be an evolving politico-military strategy of quarantine that is related both to changing patterns of political conflict and to shifting public anxieties about 
national security and where it is perceived to be under threat. Recognizing the centrality of containment emphasizes the political purpose behind the creation of these camps and in doing so provides an explanation that augments analyses of the camp as paradigmatic of exception or biopolitics. These findings are discussed in more detail below, following a brief overview of camps of containment.

\section{Camps of Containment}

Recognizing camps as a product of modernity, Bauman has characterized the twentieth century as "the century of camps."13 I would argue that the development of camps is rooted in a less-modern modernity than Bauman suggests: beginning not with the long twentieth century but rather the late eighteenth century. The few existing genealogies of encampment begin with concentration camps and the role of colonialism in the generation and reproduction of a technology of extermination. ${ }^{14}$ This overlooks a crucial earlier phase in the history of encampment, that of prisonerof-war camps.

\section{Prisoner-of-War Camps (1790s-Present)}

As with refugee camps, prisoner-of-war camps are a relatively recent innovation. Throughout much of the history of war, enemy prisoners were killed, enslaved, or held for a short period before being ransomed, released in a prisoner exchange, or paroled (i.e., a pledge not to re-enter hostilities). It was not until the French Revolutionary Wars (1792-1802) that for the first time large numbers of enemy prisoners were detained until the end of hostilities. The first known prisoner-of-war camp was created in 1796 in England. By the end of the Napoleonic Wars (I8I5), there were nine purpose-built POW prison camps across Britain. Prisoners were also detained in decommissioned naval vessels ("hulks") moored in ports. In total, more than I0o,ooo French POWs were detained in Britain over the course of the wars. ${ }^{15}$ Detention conditions varied by prisoners' military rank. Low-ranking soldiers were imprisoned in the hulks and camps, where food was insufficient and disease flourished. Officers were granted a modified form of parole. Unlike conventional parole, they were not permitted to return to France but were kept within Britain. However, they were not held in the hulks or camps but were allowed to live in the community with restrictions on their movement, such as an evening curfew and a commitment to remain within one mile of their residence. ${ }^{16}$

In another parallel with the refugee camp the history of POW camps has received relatively little academic attention, though the widespread use of encampment represented a crucial transformation in responses to military prisoners. It is important to recognize that containment of prisoners occurred because previous systems for dealing with enemy prisoners became less viable. During the Napoleonic Wars, substantially more French soldiers than British soldiers were taken prisoner. This reduced the French incentive to participate in prisoner exchange by, in effect, devaluing the exchange rate. Parole became less appealing to Britain when it became apparent that French officers frequently violated their parole promise and reentered the conflict. Ultimately, the transformation in the treatment of prisoners of war must be understood in the context of sovereign and military reform throughout Europe, including the move from mercenary armies toward a professional military and the displacement 
of aristocratic privilege from the center of military culture. These wider transitions were realized to a new extent during the Napoleonic Wars, in light of "the French revolutionary attack on established cultural practices, and [the emergence of] new French conceptions of citizenship, soldiers and war." ${ }^{17}$ In this context of new understandings of patriotism and of the nation, captured prisoners could no longer be depended on to act in accordance with either mercenary motivations or aristocratic values: they were loyal to their national army rather than to a generic soldier's code. Prisoner-of-war camps thus served a strategic purpose in preventing the return of combatants to conflict-but camps were necessary only because the character of war had fundamentally changed.

POW camps were institutionalized over subsequent conflicts, including the American Civil War (I86I-65), which similarly began under a prisoner-exchange system and ended with the existence of a dense network of close to I50 camps. More than $4 \mathrm{IO}, 000$ men were held in camps over the course of the war, in conditions that are still notorious today. More than 50,000 people died in the Civil War prison camps, largely due to unsanitary and overcrowded conditions, which were worsened by deliberate abuse of prisoners. ${ }^{18}$ Prisoners and their families perceived the very existence of POW camps as a tactic of war intended to exacerbate suffering in an already brutal conflict. Yet at the same time that thousands of men were dying of starvation and disease in POW camps, a nascent effort to regulate conflict was underway, through the Lieber Code of 1863. The Lieber Code focused on practices for prisoner exchange and parole rather than the use and management of camps and there is little to suggest that it affected the use of POW camps during the Civil War. After the war ended, however, its provisions on the humane treatment of prisoners of war formed the basis of a criminal prosecution of a former commander of Andersonville prison camp, Captain Henry Wirz, who was convicted of war crimes and hanged. ${ }^{19}$

Prisoner-of-war camps became a routine feature of international conflict, reaching their peak use during World Wars I and II when captured combatants were held in camps in Russia, Germany, Japan, and throughout the UK, United States, and Canada. By one estimate, in 1944 nine million POWs were held in camps in Germany alone. ${ }^{20}$ Again, illness and epidemics were common, as was the abuse and exploitation of prisoners. In Asia, Russia, and Europe, hundreds of thousands of men died undergoing forced labor and death marches. In France, German prisoners were used to conduct mine clearance, causing the death or injury of two thousand men each month. ${ }^{21}$ It is a tribute to human resilience that even in the most repressive conditions of encampment and incarceration, prisoners resisted. Resistance was expressed in numerous ways: refusal to follow orders, protest, and the quintessential prisoners' resistance-escape. From British officers in Colditz to interned Irish Republicans in Belfast, escape was a constant desire, even elevated to the status of a responsibility. ${ }^{22}$ As Bashford and Strange emphasize, "This history of protest against detention is as important to recognise as the techniques of detention themselves." 23

It is notable that as the material architecture of encampment expanded, so did a legal architecture for the protection of those held in camps. From the Lieber Code onward, numerous international treaties mandated the humane treatment of prisoners of war, including the Brussels Declaration of I874, the Hague Declarations of I899 
and 1907, the Geneva Conventions of 1929 and 1949 and their Additional Protocols of 1977. These treaties had a number of important consequences: they situated responsibility for prisoners of war with the national military; established containment as the appropriate humane treatment of POWs (as opposed to exchange or parole); defined a baseline of humanitarian protection; and, finally, created a system of status determination to decide who was entitled to that protection.

\section{Internment Camps (189os-Present)}

A second category of "camps as containment" is internment camps. Indeed, the two might even be considered co-extensive, as the essence of internment is the containment of a category of people on the basis of their identity rather than their individual actions. Internment has most commonly been justified on grounds of medical quarantine or national security, but the spectrum of internment past and present includes labor camps, political re-education camps, and the most notorious camps of all, concentration camps. ${ }^{24}$

The discussion below focuses on internment of civilian populations in war, as perhaps the purest example of a camp established solely for containment. Concentration camps are now inescapably associated with extermination, but the first concentration camps were essentially internment camps. In the I89os, Spanish colonists under siege in Cuba sought to reduce support to the resistance through a reconcentración policy that contained more than 500,000 civilians in camps. ${ }^{25}$ Killing civilians was not a stated goal but little was done to avert it, and conservative estimates suggest at least 100,000 people in these camps died from starvation and disease. ${ }^{26}$ Despite the terrible human cost of encampment in Cuba, the model of civilian concentration in camps was rapidly adopted by other colonial powers including the United States in the Philippines (1899-1902), the British in South Africa (I899-1902), Germany in Deutsche Sud-West Afrika (1904-7), and Italy in Libya (1928-32).

Comparing concentration camps and refugee camps has been described by some authors as polemical and disrespectful to victims of the Holocaust and defended by others as a means of honoring their suffering. ${ }^{27}$ Arguably, a distinction can be made between earlier iterations of the concentration camp model (where a counterinsurgency objective was present) and their later use (where genocidal intent was paramount). ${ }^{28}$ To some, this distinction may seem semantic. The vast majority of deaths in the early concentration camps were due to disease rather than deliberate killing: but given the crowded conditions of encampment, epidemic spread was a likely outcome and must have been understood as such by administrators. Whether disease was an intentional tool of population control or whether administrators were simply indifferent to "native" deaths, racism was from the outset deeply rooted in the concentration camp model. ${ }^{29}$ Nevertheless, the first concentration camps were essentially a military tactic. Just as prisoner-of-war camps responded to the changing character and composition of military forces, internment camps responded to a new form of conflict. Colonial authorities were under attack from irregular guerrilla groups that gained strength and support from the local civilian population and were not always distinguishable from those populations. The goal was to reduce this avenue of support, and containment in camps provided a means to do so. 
A further advantage of camps was the political ambiguity that they afforded, allowing colonial administrators to control civilian populations in a manner that could be represented back home as protecting civilians from war. This dynamic is well illustrated in the context of British camps created in South Africa during the Boer War (I899-1902). More than a hundred camps were created (forty-five to contain civilian families of Boer commandoes and around sixty for native Africans), ${ }^{30}$ as part of a network of encampment that also included POW camps in South Africa, St. Helena, Ceylon, India, Bermuda, and Portugal. ${ }^{31}$ Krebs notes that the Boer War gave rise to "a frenzy of jingoism" and an equally frenzied anti-imperialist opposition. The concentration camps became central to this political contestation. In Britain, they were portrayed as munificent welfare from the British army to the families of their opponents. Politicians called them "refugee camps" and described the residents as civilians who had entered the camps voluntarily for protection. Those who visited the camps told a different story, of farm clearances and the forced encampment of women and children in conditions where as many as one-third to one-half of those confined died. ${ }^{32}$ One of those visitors was a British peace activist, Emily Hobhouse, who published a report describing camp residents as prisoners and the camps as plagued by sickness, overcrowding, insufficient food, fuel, clothes and blankets, and absent sanitation or other services. ${ }^{33}$ This report catalyzed a bitter political battle that was expressed largely in terms of gender and vulnerability but was in essence a question of status: were the women in these camps political prisoners or refugees? Krebs writes:

Why didn't the War Office from the first admit that the camps were established to keep the Boer women from passing intelligence along to the commandos? In admitting that, they would have been admitting that the women were imprisoned because of their military activities, were in fact, as the Liberals and the Irish MPs were saying, prisoners of war. ${ }^{34}$

Or, in Hobhouse's words:

It is such a curious position, hollow and rotten to the heart's core, to have made all over the State large, uncomfortable communities of people whom you call refugees, and say you are protecting, but who call themselves prisoners of war, compulsorily detained, and detesting your protection. ${ }^{35}$

It is notable that the intensity of feeling for encamped Boer families was not matched with concern for encamped Africans, whose experiences were ignored at the time and continue to be overlooked today. ${ }^{36}$ It was not only in England that concentration camps were controversial and their political rationalization was hypocritical. The United States government criticized the Spanish reconcentración policy, even using it as grounds for the intervention and military occupation of Cuba-but swiftly implemented "concentration zones" in the Philippines when an earlier hearts-and-minds campaign failed to subdue insurgency. The German government criticized British cruelty in South Africa-but shortly thereafter created its own network of camps in Deutsche Sud-West Afrika (now Namibia). The camps in Namibia marked a destructive shift in the evolution of the model, taking what Everdell describes as the camp's "built-in auxiliary capacity for extermination" and making it the primary 
purpose. ${ }^{37}$ The use of camps for the Herero and Nama contributed to the decimation of these peoples in what is now recognized as the twenty-first century's first genocide. Subsequent camps consolidated the link between concentration camps and forced labor, and between concentration camps and killing, including those in Russia, throughout Nazi-occupied Europe, and more recently in the former Yugoslavia. In this evolution of the camp as a genocidal weapon, it is a curious historical coincidence that the first commissioner of the German camps in Namibia was Heinrich Goering, father of Hermann Goering, founder of the first concentration camps in Germany. ${ }^{38}$

Concentration camps were created by occupying powers in order to contain civilians. A second route in the development of internment camps was the containment by governments of "enemy aliens" who were present in their territory. Internment camps were a prominent feature of World War I, when more than 500,000 civilians were interned. The day after declaring war on Germany, Britain passed a law "transforming every foreigner born in Germany or Austria-Hungary into an 'enemy alien'” and imposing stringent restrictions on their travel, communications, and trade. ${ }^{39}$ After German submarines sank the Lusitania ocean liner-causing more than I,OOo civilian deaths - these "enemy aliens" were ordered into internment camps. As the war continued, internment camps spread around the world. Alongside the development of these camps, Pitzer notes, was an emerging "administrative bureaucracy" that linked internment camps to international agencies and allowed internees to train and study for recognized qualifications, even Oxbridge degrees. As a result, "by 1918, the imprisonment of civilians seemed unexceptionable. The most humane parts of the camps - the Red Cross packages, the libraries, the orchestral performances-had normalized the idea of wartime internment." 40

In this emerging architecture of protection and normalization of containment, the evolution of internment camps shows notable parallels with the prisoner-of-war camp. Other striking parallels between the models include material architecture (a topic beyond the scope of this essay but one emerging as a distinct field of study) and the rapid international adoption of the model despite its capacity for abuse or destruction. Similar, though less extreme, tendencies can also be seen in the evolution of the refugee camp.

\section{Camps as a Response to Forced Migration (1915-Present)}

It is difficult to say when the first refugee camps were created, or to identify what we should consider to be the first refugee camp. Among the first camps to be called "refugee camps" were the British concentration camps of the Boer War. Closer to current understandings of the model are camps created for Armenians fleeing genocide in I9I5-18, or even the "dust bowl" camps established for labor migrants in Depression-era California. There may well be other, earlier examples. However, the consistent, large-scale use of refugee camps as a response to forced migration is undoubtedly a recent phenomenon, beginning during World War II. Displaced Persons (DP) camps were created across Europe, initially to house people fleeing the Nazi regime but subsequently also to accommodate people who had been freed from concentration camps or who were fleeing the Soviet Army. The policy shift is no less remarkable with more than a half-century's hindsight: at the very height of camps as 
spaces of cruelty, they were adopted as spaces of compassionate humanitarianism. ${ }^{41}$ As Arendt recognized at the time, "The world has created a new kind of human beings - the kind that are put in concentration camps by their foes and in internment camps by their friends." ${ }^{42}$ This is an extraordinary political moment, which precisely illustrates the fluidity of camps of containment and captures their paradoxical dimensions of care and control.

Subsequent decades saw a rapid proliferation of camps, beginning with refugees from Indian Partition, then from the creation of the State of Israel, and culminating in the position today, where approximately one-third of the global population of refugees and asylum seekers is housed in hundreds of camps across the global south and unknown numbers are interned in immigration detention centers in the global north. ${ }^{43}$

One important distinction between refugee camps and the other camps of containment analyzed here is longevity: once created, refugee camps tend to remain in existence for a very long time. The last Displaced Persons camp in Europe closed in 1959, nearly fifteen years after the end of the Second World War. Many other camps created in the immediate postwar years remain in existence today, including in West Bengal and in the West Bank. Camps entered an era of particular expansion during the "Second Cold War" of I977-85, when new regional conflicts led to the creation of camps in Southeast Asia, Central America, the Horn of Africa, and Southern Africa. ${ }^{44}$ As the Cold War continued, geopolitical containment agendas also led to the containment of migration. International resettlement places contracted and refugee camps became the "de facto fourth durable solution": a long-term home for displaced people. ${ }^{45}$ In that time, the creation and management of refugee camps has become a humanitarian industry, involving hundreds of international organizations in food, shelter, sanitation, education, health, and other forms of assistance.

Among the many refugee and IDP camps in existence, some are more clearly spaces of "containment" than others. Even tightly controlled refugee settlements will have some interaction with a surrounding population, whether through entrepreneurs traveling into the camp to sell goods and services or refugees traveling "outside" for work or education. Likewise, all camps will develop an internal infrastructure of schools, clinics, shops, faith centers, and other institutions of daily life. In these and myriad other ways, camps will be sites of agency, adaptation, and political organization. These aspects challenge prevailing understandings of refugee camps as wholly anarchic spaces. Yet even the least-worst camp environments produce estrangement and alienation. ${ }^{46}$ The nature of a camp is to separate populations, and interchange between camp residents and a local population does not in itself constitute a relationship of equals. The extent of exclusion varies, but some degree of segregation is inevitable.

It might be argued that the turn to encampment was an unavoidable response to unprecedented migration flows and pressures: that camps are simply a convenient, necessary (and therefore morally neutral) response to mass movement of peoples. This argument is undermined by the history of political responses to asylum, which indicates a direct preference for containment over its alternatives. In the interwar years, the leading refugee protection mechanism was the Nansen Passport, a document that 
enabled forced migrants to legally cross international borders. This initiative foundered on a shortage of state cooperation and subsequent decades saw increasing retrenchment in attitudes toward forced migrants. After World War II, Proudfoot wrote, "The one form of international action which would have provided the most substantial relief for the refugees would have been a widespread lowering of immigration barriers. Most nations, however, were prepared to do no more than suggest this course of action for their neighbors." ${ }^{4} 7$ This has become a recurring theme in the field of refugee protection.

This brief history of the refugee camp illustrates again the rapid adoption of the camp model in its application to a new category of people. It also illustrates the contrast between often inhumane conditions and a lexicon of humanitarian assistance that (while undoubtedly ethically intended) ultimately served to normalize containment as a mechanism of protection. As explained above, both POW camps and internment camps tended to be politically rationalized as a humanitarian response, even as the reality of containment was often brutal. Refugee camps may seem to have a more authentically humanitarian role, but as encampment situations increased in number and duration, problems also gathered pace. Campaigns against refugee "warehousing" highlighted human rights concerns (such as that maintaining refugees in camps violated rights to freedom of movement and choice of residence); the difficult conditions that tend to prevail in camp settings (poverty, overcrowding, lack of opportunities, exploitation in informal economy); and, perhaps most damaging of all, abuses of authority by staff of international humanitarian agencies. ${ }^{48}$ Policy reforms eventually followed. In 1997, the UNHCR produced a policy for refugees in urban areas that appeared to be predicated on an assumption that refugees "belonged" in camps and should go to camps in order to receive aid and assistance. ${ }^{49}$ Twelve years later, an updated urban refugee policy placed respect for freedom of movement and choice of residence at the center of its approach. ${ }^{50}$ Finally, in 20I4, a policy on alternatives to camps stated that UNHCR will seek to "avoid the establishment of refugee camps" wherever possible. ${ }^{51}$

However, these policy reforms must be balanced against the continuing political reality of millions of people living in hundreds of camps worldwide. Recent years have seen the creation of many new camps in Turkey and Jordan to house refugees from Syria. There has also been a massive expansion in the use of immigration detention. Since 200I, Migreurop has traced the use of closed detention spaces for migrants in Europe and the Mediterranean. Its most recent "Encampment Map" identifies 42I such centers. ${ }^{52}$ Described by Migreurop as "camps," these sites blur the line between incarceration and encampment. They are spatially bounded, biopolitical spaces of containment and segregation, but they are not temporary. These are detention centers with a continuing existence, not linked to political reform or an opening of durable solutions.

This points to an important evolution in the nature of forced migration and the perceived threat represented by forced migrants. During the Cold War, the threat was one of political ideology and potential militarization. Over subsequent decades, the perceived threat presented by refugees has been to demographic balance, to public health, to natural resources and the environment. More recently, the threat appears to 
have morphed into something more generalized. Mark Duffield has described a state of global civil war against refugees in terms of "under-developed species-life" and the "global non-insured." 53 His analysis recognizes that the dominant form of political conflict is no longer ideologically led and conducted between or within nation-states but is a global struggle between developed and underdeveloped humanity. This is a war without obvious end, and containment is a crucial strategy in its conduct.

\section{Conclusion}

Several analyses of refugee camps have recognized a common heritage with concentration camps. None, to my knowledge, has recognized the parallels with prisoner-ofwar camps. By doing so, this essay offers a new and illuminating perspective on the history of the refugee camp. Most obviously, it changes the timeframe for analysis, shifting the frame from camps as a product of the twentieth century to camps as a product of modernity (and thus, it might be argued, intrinsically related to the changing nature and role of the contemporary state). The longue durée of the camp also reveals its history of transformation and reinvention. Each evolution of the camp as containment has represented a transformation in the political response to a particular category of people, moving from a palette of responses (or a nonresponse) to a presumptive use of containment. Furthermore, the camp itself has been repeatedly reinvented for different categories of people_combatants, civilians, "enemy aliens," refugees-while retaining a fundamental continuity in central features and purpose. This analysis shows the camp to be considerably more adaptive than comparisons focused solely on extermination camps might suggest.

The salience of a category of camps of containment is reinforced by blurred boundaries between the different models. In I803, Napoleon interned all British male civilians of military age and called them "prisoners of war." In the Anglo-Boer War, British politicians frequently referred to the concentration camps as "refugee camps." In World War II, the British government described its internment camp on the Isle of Man as a "prisoner-of-war camp" though it contained civilians as well as enemy prisoners. The camp models seem almost interchangeable. More surprisingly, so do the resident populations. In World War II, people released from concentration camps were promptly confined in displaced person camps where, as the war drew to a close, they were joined by increasing numbers of Nazi prisoners of war. This was not unique to Europe. Refugees who were resettled to Australia during the war were interned as "enemy aliens," in the same camps and under the same conditions as Nazi and Fascist prisoners of war. ${ }^{54}$ The apparent absurdity of this becomes explicable only when we understand the camp in relation to its purpose of containment, when we recognize that the POW camp, internment camp, and refugee camps are not separate species but are essentially similar.

The history of camps of containment shows them to be spaces of contradiction in numerous respects. They are sites that can perform humanitarian functions of protection, security, and service delivery while simultaneously serving political goals of containment and control. They are sites for the generation of human rights protection and for the abrogation or evasion of those protections. They are sites characterized by restricted autonomy and by resilient agency. They are sites that render 
unwanted populations invisible but which nevertheless consistently generate public outcry and opposition. Perhaps the most profound contradiction is that a model that exemplifies stasis has proven so dynamically adaptable.

This provides important context to the camp, reinforcing its function as a mechanism for dealing with those who are considered the other. Malkki has described refugees as "matter out of place," a term that can equally be applied to prisoners of war or enemy aliens..$^{55}$ In effect, encampment is a strategy used against misfits, and it is acceptable to a wider public for that very reason. As Fassin writes, "A situation that should be considered intolerable is in fact tolerated because the public order is threatened by immigrants, enemies, communists, gypsies, Jews, and collaborators." 56 The essential function of these camps is to contain a population category apart from the wider population. This has a dual function, regulating the behavior and movement of those inside the camp boundaries but arguably performing an even more critical role in regulating relationships with those outside. As Bauman recognizes, estrangement and segregation are not byproducts of containment but its primary function. Cause and effect are inseparable here. The segregation of categories of people has been used repeatedly throughout history to define and discipline those who are different or unwanted, and their (real or perceived) difference is further heightened by segregation. ${ }^{57}$ Camps of containment, then, can be understood as both a product and a cause of alienation and estrangement.

A recurring theme in this genealogy of the camp has been a tension between inhumane conditions and humanitarian rationales. When people are put in camps, negative consequences abound, from the epidemic spread of disease, to food shortages, to labor exploitation and the direct abuse of power. Yet their use has consistently been challenged, with calls to abolish the British camps in South Africa echoed in our own time by the campaign to end refugee "warehousing." ${ }^{58}$ Furthermore, contrary to the perception that camps exist in a state of extralegal exception, they have consistently been sites for the generation and application of new legal regimes. Texts from the Geneva Convention on the Treatment of Prisoners of War (1929) to the SPHERE Handbook (20II) have set standards for the humane treatment of those who are held in camps - and in doing so, they have repeatedly joined a humanitarian discourse of protection with acceptance of containment as a mechanism of protection.

However, while camps of containment exist within a struggle for the ethical management of war, they are at heart a mechanism of war rather than a constraint on it. Recognizing prisoner-of-war camps as antecedents of the refugee camp clarifies the extent to which the evolution of camps of containment is linked to the changing character of conflict, or, differently phrased, to changing perceptions of threats to security. For example, detention of prisoners of war began when exchange, parole, and conscription systems became less valuable. Internment of civilians during war began when guerrilla warfare blurred the principle of distinction between combatants and civilians. Camps for forced migrants were used when wars began to generate massive migration outflows. The different iterations of camps of containment thus reflect evolving practices of international conflict. They also indicate a changing anxiety about national security and where it is perceived to be under threat: from prisoners being released back into the conflict; from civilians providing intelligence 
and support to insurgents; or, in our own time, from forced migrants as the "global noninsured." The continued use of refugee camps, IDP camps, and immigration detention camps suggests that forced migrants will continue to be targets of containment for some time to come. ${ }^{59}$

\section{NOTES}

This essay began as an introductory lecture to the M.Sc. module "Camps and Containment" that I taught at the University of Oxford's Refugee Studies Centre from 2012 to 20I5. Thanks to my students in that course for their insightful questions. Thanks also to Maja Janmyr and Are Knudsen for the invitation to participate in this issue, and to the anonymous reviewers for their comments on previous drafts. A version of this essay was presented at the Oxford Refugee Studies Centre in May 2016. I am grateful to the audience for their excellent comments.

I. This number includes ten million people recognized as "of concern" to the United Nations High Commissioner for Refugees (UNHCR), more than I.5 million Palestinian refugees from 1948 and 1967 , and an unknown number of refugees, asylum seekers, and internally displaced persons who live in camps but are not registered with the UNHCR. The UNHCR's Global Trends Data 2014 identifies 224 "planned/managed camps," II "reception/transit camps," and I27 "self-settled camps" (see table is).

2. Anna Schmidt, "Camps versus Settlements," Forced Migration Online (2003); also, for information on distinguishing self-organized refuges, sorting centers, spaces of confinement, and unprotected reserves, see Michel Agier, Managing the Undesirables: Refugee Camps and Humanitarian Government, (Cambridge: Polity Press, 201I), 37-59.

3. Didier Fassin, Humanitarian Reason: A Moral History of the Present. (Berkeley: University of California Press, 2012), 149-57; Guglielmo Verdirame, The UN and Human Rights: Who Guards the Guardians? (Cambridge: Cambridge University Press, 20II), 269.

4. Fassin, Humanitarian Reason; Agier, Managing the Undesirables; Liisa Malkki, "Refugees and Exile: From 'Refugee Studies' to the National Order of Things," Annual Review of Anthropology 24 (1995): 495-523, 498.

5. Giorgio Agamben, Homo Sacer: Sovereign Power and Bare Life, (Stanford, Calif.: Stanford University Press, 1998); Bülent Diken and Carsten Bagge Lausten, The Culture of Exception: Sociology Facing the Camp (Abingdon: Routledge, 2005); Jenny Edkins, "Sovereign Power, Zones of Indistinction and the Camp," Alternatives: Global, Local, Political 25, no. I (January-March 2000): 3-25; Adam Branch, "Humanitarianism, Violence and the Camp in Northern Uganda," Civil Wars II, no. 4 (2009): 477-50I; David Keen, "The Camp and the Lesser Evil: Humanitarianism in Sri Lanka," Conflict, Security and Development I4, no.I (2014): I-3.

6. Jennifer Hyndman, Managing Displacement: Refugees and the Politics of Humanitarianism (Minneapolis: University of Minnesota Press, 200o); Julie Peteet, Landscape of Hope and Despair: Palestinian Refugee Camps (Philadelphia: University of Pennsylvania Press, 2005).

7. Liisa Malkki, "News from Nowhere: Mass Displacement and Globalized 'Problems of Organization," Ethnography 3, no. 3 (September 2002): 352-53; Gaim Kibreab, "Why Governments Prefer Spatially Segregated Settlements for Urban Refugees," Refuge 24, no.I (Winter 2007): 27-35.

8. Malkki, "News from Nowhere," 352; Agier, Managing the Undesirables, 84; Guglielmo Verdirame and Jason Pobjoy, "The End of Refugee Camps?," in Ashgate Research Companion to Migration Law, Theory and Policy, ed. Satvinder S. Juss (Farnham: Ashgate, 20I3), 472. 
9. Andrew Shacknove, "From Asylum to Containment," International Journal of Refugee Law 5, no. 4 (1993): 516-33.

Io. Emanuel Marx, "The Social World of Refugees: A Conceptual Framework," Journal of Refugee Studies 3, no. 3 (1990): 189-203, 197; Guglielmo Verdirame and Barbara Harrell-Bond, Rights in Exile: Janus-Faced Humanitarianism (New York: Berghahn Books, 2005), 338.

II. Anna Feigenbaum et al., Protest Camps (New York: Zed Books, 2013), 4-5.

I2. Kirsten McConnachie, Governing Refugees (Abingdon: Routledge, 20I4).

13. Zygmunt Bauman, "The Century of Camps," in The Bauman Reader, ed. Peter Beilharz (Oxford: Blackwell, 2000), 266-8I; Zygmunt Bauman, Modernity and the Holocaust (Cambridge: Polity, 1989).

I4. Federico Rahola, “The Space of Camps: Towards a Genealogy of Places of Internment in the Present," in Conflict, Security and the Reshaping of Society, ed. Alessandro Dal Lago and Salvatore Palidda (Abingdon: Routledge 20I0); Anne Applebaum, “A History of Horror,” New York Review of Books, October I8, 200I; Agamben, Homo Sacer; Hyslop, “The Invention of the Concentration Camp," 253; Didier Fassin, "Compassion and Repression: The Moral Economy of Immigration Policies in France," Cultural Anthropology 20, no. 3 (August 2005): 362-87.

I5. Gavin Daly, "Napoleon's Lost Legions: French Prisoners of War in Britain, I803-I8I4," History 89, no. 3 (July 2004): 363-64.

I6. Ibid., 374 .

I7. Ibid.; David A. Bell, The First Total War: Napoleon's Europe and the Birth of Warfare as We Know It (Boston: Houghton Mifflin, 2007).

I8. Benjamin Cloyd, Haunted by Atrocity: Civil War prisons in American Memory (Baton Rouge: Louisiana State University Press, 2010), I, I9.

19. Wirz's prosecution is perceived by some as politically motivated scapegoating. In I909, a monument to Wirz was erected in Andersonville inscribed on one side to "the victim of a misdirected popular clamor." Another side of the memorial includes a quotation from Ulysses S. Grant: "It is hard on our men held in southern prisons not to exchange them . . to release all rebel prisoners would insure Sherman's defeat." See a description of the Wirz monument at National Park Service website, accessed September 23, 2015, http:/www.nps.gov/ande/learn/ historyculture/wirz-mon.htm.

20. John Nichol and Tony Rennell, The Last Escape: The Untold Story of Allied Prisoners of War in Europe, 1944-45 (London: Penguin Books, 2003), xv.

2I. S. P. MacKenzie, "The Treatment of Prisoners of War in World War II," Journal of Modern History 66, no. 3 (September 1994): 503, 508.

22. Kieran McEvoy, Kirsten McConnachie, and Ruth Jamieson, "Political Imprisonment and the "War on Terror,'” in Handbook on Prisons, ed. Yvonne Jewkes (Cullompton: Willan, 2007), 309.

23. Alison Bashford and Carolyn Strange, "Asylum-Seekers and National Histories of Detention," Australian Journal of Politics and History 48, no. 3 (September 2002): 522.

24. For an investigation of medical quarantine stations in Australia and the common heritage between these stations and contemporary sites of immigration detention, see ibid., 509-27.

25. Usually believed to have originated in 1895 , the reconcentración policy was first mooted almost thirty years earlier. See Iain R. Smith and Andreas Stucki, "The Colonial Development of Concentration Camps (I868-1902)," Journal of Imperial and Commonwealth History 39, no. 3 (20II): 4I7-37. 
26. John Lawrence Tone, War and Genocide in Cuba, I895-1898 (Chapel Hill: University of North Carolina Press, 2006), 193.

27. See, for example, Fassin, Humanitarian Reason, I52; Bauman, Modernity and the Holocaust.

28. See Smith and Stucki, "The Colonial Development of Concentration Camps."

29. Jonathan Hyslop, "The Invention of the Concentration Camp: Cuba, Southern Africa, and the Philippines, 1896-1907," South African Historical Journal 63, no. 2 (20II): 25I-76, 25I; Sven Lindqvist, Saharan Journey, trans. Joan Tate (London: Granta, 20I2).

30. Stephen A. Royle, "St. Helena as a Boer Prisoner of War Camp, I900-2: Information from the Alice Stopford Green Papers," Journal of Historical Geography 24, no.I (January 1998): 54.

3I. Ibid., 55 .

32. Ibid., 54 .

33. Hobhouse, Report of a Visit to the Camps of Women and Children.

34. Paula M. Krebs, "'The Last of the Gentlemen's Wars': Women in the Boer War Concentration Camp Controversy," History Workshop Journal 33 (1992): 42.

35. Hobhouse, Report of a Visit to the Camps of Women and Children, 6.

36. Krebs, "'The Last of the Gentlemen's Wars," 38-56.

37. William R. Everdell, The First Moderns: Profiles in the Origins of Twentieth-Century Thought (Chicago: University of Chicago Press, 1997), I26.

38. Applebaum, "A History of Horror."

39. Andrea Pitzer, "Enemy Aliens," Lapham's Quarterly 8, no. I (Winter 2015), accessed January 4, 20I5, http://www.laphamsquarterly.org/foreigners/enemy-aliens.

40. Ibid.

4I. G. Daniel Cohen, In War's Wake: Europe's Displaced Persons in the Postwar Order (Oxford: Oxford University Press, 2012); Peter Gatrell, Free World? The Campaign to Save the World's Refugees, 1956-1963 (Cambridge: Cambridge University Press, 20II).

42. Hannah Arendt, "We Refugees," in Altogether Elsewhere: Writers on Exile, ed. Marc Robinson (New York: Harvest, 1994), no.

43. In 2012, Migreurop's "Carte des Camps" identified close to 500 "camps" across Europe (including sites of administrative detention, of detention for asylum-seekers awaiting status determination, and of detention for people awaiting deportation). See http://www.migreurop.org/.

44. Gil Loescher, UNHCR in World Politics (Oxford: Oxford University Press, 200I), 2 II.

45. Shacknove, "From Asylum to Containment"; B. S. Chimni, "From Resettlement to Involuntary Repatriation: Towards a Critical History of Durable Solutions to Refugee Problems," Refugee Survey Quarterly 23, no. 3 (October 2004): 55-73.

46. See Zygmunt Bauman, Globalization: The Human Consequences (Cambridge: Polity, 1998), 106.

47. Malcolm J. Proudfoot, European Refugees, 1939-s2: A Study in Forced Population Movement (London: Faber and Faber, 1957), 31.

48. Merrill Smith, "Warehousing Refugees: A Denial of Rights, a Waste of Humanity," World Refugee Survey 2004; Guglielmo Verdirame and Barbara Harrell-Bond, Rights in Exile; Gil Loescher, James Milner, Edward Newman, Gary Troeller, eds., Protracted Refugee Situations: Politics, Human Rights, and Security Dimensions (New York: United Nations University Press, 2008).

49. UNHCR, Comprehensive Policy on Urban Refugees, Geneva, March 1997, para. 6, accessed September 23, 20I5, http://www.refworld.org/pdfid/41626fb64.pdf. 
50. UNHCR, Policy on Refugee Protection and Solutions in Urban Areas, September 2009, accessed June 8, 20I4, http://www.refworld.org/docid/4ab8e7f72.html.

5I. UNHCR, Alternatives to Camps (20I4), accessed January IO, 20I5, http://www.unhcr.org/ $5422 \mathrm{~b} 8$ fog.html.

52. Migreurop, accessed January 8, 2015, http://en.closethecamps.org/2013/II/23/migreurops -encampment-map/.

53. Mark Duffield, "Global Civil War: The Non-Insured, International Containment and Post-Interventionary Society," Journal of Refugee Studies 2I, no. 2 (2008): 145-65.

54. Bashford and Strange, "Asylum-Seekers and National Histories of Detention," 520.

55. Liisa Malkki, Purity and Exile: Violence, Memory, and National Cosmology among Hutu Refugees in Tanzania (Chicago: University of Chicago Press, 1995), 8.

56. Fassin, "Compassion and Repression," 378-80.

57. See Zygmunt Bauman, Globalization, I06.

58. Smith, "Warehousing Refugees."

59. Jonathan Paye-Layleh, "Ebola Outbreak: Quarantine Camps in West Africa at Breaking Point," Independent, October 23, 20I4; Geoff Manaugh and Nicola Twilley, "Ebola and the Fiction of Quarantine," New Yorker, August II, 2014. 